\title{
The fable paradigm of the gender pay gap: Evidence from Portuguese private firms
}

\author{
Carlos Duarte $^{1}$, Maria Carapeto ${ }^{2}$, Ivo Pereira ${ }^{3}$ \\ (1. Department of Management, Polytechnic Institute of Tomar, Tomar 2300-313, Portugal; 2. Department of Finance, Cass \\ Business School, London EC1Y 8TZ, UK; 3. Department of Finance, ISCTE-IUL, Lisbon 1649-026, Portugal)
}

\begin{abstract}
This study investigates gender income disparity in Portuguese firms using separate Tobit models for men and women. While job segregation seems to be one of the major sources of gender disparity, women do not appear to be systematically underpaid in predominantly female occupations, regardless of the industry. The authors found that gender pay gap is larger in domestic firms, and it increases with employees' accumulated tenure and decreases with advanced education for women and on labor market entry. Despite showing some encouraging cracks, the glass ceiling still continues to prevent women from reaching top management positions. Finally, despite it appears wage disparity does exist, and it will probably continue to exist, the results point towards a window of opportunity for women.
\end{abstract}

Key words: segregation; gender pay gap; compensation policy; Tobit model

\section{Introduction}

Most papers that investigate the issue of wage disparity between genders have found that there is a gender pay gap, mainly driven by job segregation (i.e., women and men being attracted towards different kinds of occupations) and also by an uneven load of family and home responsibilities assumed by women (Babcock \& Laschever, 2003; Blau \& Kahn, 2007; Boushey, 2008; Bowlin \& Renner, 2008; Cornelius \& Skinner, 2008).

While disparity in earnings may result from differences in skills, qualifications and levels of experience relevant to employers (Blau \& Kahn, 2007; Betrand \& Hallock, 2001), Van der Meer (2008) states that the gap in productive characteristics (e.g., education and tenure) between men and women has been reducing over time. Moreover, Bowlin and Renner (2008) argue that inequity is negligible at top management levels, though Adams, Gupta and Leeth (2009) and Ryan and Haslam (2009) emphasize that women experience considerable difficulty breaking into top positions. Still, the gender pay gap seems to persist in spite of anti-discrimination legislation and the closing of the educational gap between men and women. In this way, some authors have identified differences in employment possibilities and remuneration as gender discrimination and failure in labor markets that ought to be corrected through public policy intervention (Babcock \& Laschever, 2003).

The majority of gender studies analyzed the largest and wealthiest countries, namely the US and the UK.

Carlos Duarte, Ph.D., professor, Department of Management, Polytechnic Institute of Tomar; research fields: gender discrimination, pay policies, corporate governance.

Maria Carapeto, Ph.D., senior lecturer, Department of Finance, Cass Business School; research fields: bankruptcy reorganization and liquidation, mergers and acquisitions, corporate restructuring.

Ivo Pereira, Ph.D. candidate, Department of Finance, ISCTE-IUL; research fields: pay policies, family business, corporate governance. 
However, the wage gap is considerably greater in the Anglo-Saxon economies compared with many other countries, which might invalidate some findings from previous studies (ITUC Report, 2008). Moreover, the availability of paid family leave and public support for childcare in many European economies (unlike the situation in the US) may constitute a key variable that could potentially affect the results. In this way, this study investigates the gender pay gap in Portugal, a representative small European country that ranks 39th by GDP (International Monetary Fund World Economic Outlook database, October 2008). The first contribution of this paper is thus to consider the relevance of previous findings to smaller and less rich economies, using a sample of 75 small and middle-sized establishments in 2003 that include 3,953 employees, classified by gender and function: top managers, middle managers, technicians and staff.

Unlike previous research which was based on the whole economy, this paper examines the gap using a unique dataset where each firms' compensation program is matched to its financial characteristics. In fact, previous authors have recognized the need to account for employer characteristics in this type of study, such as firm size (Brown \& Medoff, 1989; Agell \& Bennmarker, 2007), profits (Blanchflower, Oswald \& Sanfey, 1996), industry (Gibbons \& Katz, 1992) and productivity (Gneezy, Niederle \& Rustichini, 2003). Hence, the second contribution of this paper is to quantify the role of both individual workers and the workplace itself at explaining the gender pay gap.

The results support the existence of a "glass ceiling" in Portugal, with women suffering from an overall average gender pay gap of 2.2 percent, with advantages of 4 percent at top management and staff levels, but disadvantages of 12 percent and 28 percent at middle management and technician levels, respectively. This study finds that the gap is larger in domestic firms, that it increases with employees' accumulated tenure, and decreases with advanced education for women and on labor market entry. However, and in contrast to previous work, the study finds deeper gaps in larger and more profitable firms. At the same time, the gap does not seem to be related to predominantly "female" areas and industries, and the glass ceiling is not weaker in female-dominated firms either.

\section{Literature review and hypotheses setting}

Some researchers have found that there is a gender pay gap and that it is largely driven by: (1) job segregation (i.e., women and men gravitate towards different kinds of occupations) and (2) a disproportionate share of family and home responsibilities borne by women (Boushey, 2008; Bowling \& Renner, 2008; Blau \& Khan, 2006, 2007; Babcock \& Laschever, 2003).

According to the human capital theory (Mincer, 1974; Becker, 1993), the gender gap in earnings is attributed to differences between male and female employees in productivity-related endowments. It was indeed the case that men did generally have more education than women at one time. However, in some countries, there is now educational parity, and in some areas, the trend has been reversed-Women are currently better educated than men (Blau \& Khan, 2007). As women have reached, or exceeded, the educational levels of men, they have also progressively gained more access to jobs that previously had been primarily held by men. Women have increasingly managed to obtain skilled jobs in both the public and private sectors, including management, business, and finance (Betrand \& Hallock, 2001; Leung, 2003). Almquist (1987) found that wage differences between men and women in occupations, requiring comparable skills, could be due to the fact that women are channeled into a limited number of occupations. Thus, it is not necessarily the case that the gender wage gap is the 
result of overt discrimination (i.e., unequal pay for the same work in the same firm), rather it grows out of occupational segregation. Assuming that men do still enjoy an internal market advantage, there are two possible reasons that can partly explain the gender pay gap: (1) Men genuinely have a stronger commitment to the labor market, or employment segregation by gender is related to the division of the labor market in distinct sectors/segments and the existence of disadvantaged groups of workers into sectors/segments with the worst pay conditions; (2) The labor market is divided into distinct sectors/segments, some desirable and others less so, and males and females are funneled into those sectors/segments according to their gender. If one accepts that, then male-female income disparity will stem from men being in "primary" sectors/segments of the market and women in "secondary" ones. However, dual/segmented labor market theories have not fully identified the causes of employment segregation by gender.

The constrained decisions that men and women make about work and home issues are indeed another source of the pay gap. Women are more likely than men to work fewer hours and to take time out of the labor market. Such decisions result in very different pay for men and women, with women on average having lower rates of job tenure than men (Blau \& Khan, 2007), and married women most likely to take leaves (Betrand \& Hallock, 2001). Such interruptions in employment have an even greater negative impact on future pay increases, in particular if the employee lacks previous work experience. In fact, Neumark (1993) found that the longer the period of absence, the lower the future increases in pay, despite the length of previous employment. It may well be the case that employers are uncertain about undertaking human capital investments in women, fearing that women will not stay with the firm, but will rather choose to stay at home (Betrand \& Hallock, 2001).

Becker (1957) and Hellerstein, et al (2002) say that larger firms enjoy higher market power and can thus afford more discrimination, and Betrand and Hallock (2001) find that female top managers typically work for smaller firms. However, Neathey, et al (2003) and Yurtoglu and Zulehner (2007) amongst many others argue that larger firms tend to monitor their relative pay structures very closely, while at the same time, being subject to a wider scrutiny from the media and the public. In this way, one would expect larger firms that are in competitive labor markets to conduct "equal pay audits", and hence a negative relation between the gender pay gap and the size of the firms. Firm ownership is another factor that could potentially explain the gender pay gap. Multinational firms are more exposed to competition than purely domestic firms and for this reason, the magnitude of the gender pay gap in these firms is likely to be smaller. Aitkens, Harrison and Lipsey (1996) show that foreign-held firms tend to give higher compensation than domestic firms. Given that the former is more exposed to competition, it is expected that the gender pay gap will be smaller in multinational firms. Hellerstein, Neumark and Troske (2002) find that firm profitability has no impact on the relative gender pay, despite the anticipation that more profitable and high-growth firms could potentially practice smaller gaps. Hence, this study expects to find no relation between these variables and the gender pay gap.

Hypothesis 1: The size of the pay gap between male and female employees will be (1) negatively related to the size of the firms, (2) positively related to the domestic nature of the employer, and (3) unrelated to firm profitability and growth.

Human capital variables such as age, education, training and experience, relate very unequivocally to the ability of the employee and hence should have a direct effect on pay. Kunze (2005), Yurtoglu and Zulehner (2007), and Blau and Kahn (2007) find that gender segregation related to occupational qualifications is responsible for a significant portion of the wage gap, though Neathey, Dench and Thomson (2003) argue that returning to university for further qualifications makes little difference to the pay gap. Blau and Kahn (2007), and Chevalier (2007) 
however show that the gap narrows with improvements in the level of qualifications of women, so the gender pay gap should be negatively related to the level of education. Arulampalam, Booth and Bryan (2007), and Jacobs (1992) find that the gender pay gap is typically less significant at the level of entry. Jacobs (1992) observes however a significant pay gap after several years of tenure. Given that tenure and educational qualifications are determinants of performance (Duarte, Esperança \& Curto, 2006), if women enjoy less tenure and display lower levels of qualification, then they will earn lower wages (Arulampalam, et al., 2007), despite no differences in starting salaries of males and females.

Hypothesis 2: The size of the pay gap between male and female employees will be (1) negatively related to the level of education, (2) small on labor market entry, and (3) greater with accumulated tenure.

Chevalier (2007) finds evidence of a large degree of segregation by sex in the labor market. Women tend to concentrate in low-paying industries and are typically channeled into areas of study that are less likely to lead to better compensation (Pfeffer \& Blake, 1987). When it comes to pay and promotion, the existence of a "glass ceiling" that hinders the chances of women from reaching top management positions substantially aggravates the pay gap, as the few females who previously managed to reach the top are probably not able to influence the system. Huffman and Velasco (1997), Pfeffer and Blake (1987) and Reilly and Wirjanto (1999) argue that firms and industries that employ a high percentage of women typically pay lower salaries across the board, though the gender pay gap seems to narrow with the rise in the number of female managers, as documented by Jacobs (1992), who was more likely to promote women to top positions (Phillips, 2005).

Hypothesis 3: Firms with a high proportion of women employees (1) will offer lower pay, but (2) will give higher hierarchical positions to women.

\section{Data and descriptive statistics}

The sample used in this study is from 2003 and includes 3,953 employees working for 75 small and middle-sized Portuguese firms (with one hundred or more employees) classified by gender and by function level-top executives, middle-level managers, technicians and staff. The data are from the Portuguese representative affiliate of a Human Resources Consulting firm and Dun \& Bradstreet.

Table 1 Characteristics of the 75 firms of the sample

\begin{tabular}{|c|c|c|c|c|c|c|c|}
\hline Type & \multirow[b]{2}{*}{58} & Sector & \multicolumn{2}{|r|}{ Nationality } & \multicolumn{3}{|c|}{ Size (number of worker) } \\
\hline Multinational & & Consumption Goods & 6 & United Kingdom & 3 & $100-250$ & 30 \\
\hline \multirow[t]{9}{*}{ Domestic } & 17 & Automotive & 8 & United States & 12 & $251-500$ & 15 \\
\hline & & Distribution & 11 & Germany & 15 & $501-1,000$ & 13 \\
\hline & & Electrical & 7 & France & 6 & $1,001-2,000$ & 9 \\
\hline & & Pharmaceutical & 8 & Spain & 2 & $2,000-5,000$ & 4 \\
\hline & & Chemical & 8 & Switzerland & 3 & $>5,001$ & 4 \\
\hline & & Industrial & 5 & Denmark & 5 & & \\
\hline & & Service & 7 & Others & 12 & & \\
\hline & & Finance & 11 & Portugal & 17 & & \\
\hline & & Telecommunications & 4 & & & & \\
\hline
\end{tabular}

Table 1 shows the characteristics of firms in the sample. Therefore it is confident that the sample reflects the Portuguese reality in what concerns private sector activity.

The variables include the annual base pay, function level, function area, education attainment, age, years of 
tenure in current job, and firm characteristics such as: size, sales growth, profitability, industry and ownership (see Table 2).

The univariate analysis of the data shows that only 7.7 percent of women reach top management, though they account for 41 percent and 56 percent of all middle-level managers and technicians, respectively. Fig. 1 expands on those the results.

Gap means the ratio of average pay of female to average pay of male by function level minus one.

Table 2 Variables considered in the econometric models

\begin{tabular}{|c|c|c|c|}
\hline Variables & Description & Scale & Measured as: \\
\hline \multicolumn{4}{|l|}{ Dependent } \\
\hline AnnualBasePay & Annual Base Pay & Interval & \\
\hline FemaleBasePay & Annual Female Base Pay & Interval & \\
\hline VarDumFem & Existence of Annual Female Variable Pay & Binary & \\
\hline FemaleVar & Annual Male Variable Pay & Interval & \\
\hline MaleVar & Annual Female Variable Pay & Interval & \\
\hline MaleBasePay & Annual Male Base Pay & Interval & \\
\hline \multicolumn{4}{|l|}{ Explanatory } \\
\hline FGenAdm & Dummy variable of the functional area & Binary & $\begin{array}{l}1=\text { if the employee is in the general administration area; } \\
0=\text { no }\end{array}$ \\
\hline Ffin & Dummy variable of the functional area & Binary & $1=$ if the employee is in the financial area; $0=$ no \\
\hline FIT & Dummy variable of the functional area & Binary & $\begin{array}{l}1=\text { if the employee is in the information technology area; } \\
0=\text { no }\end{array}$ \\
\hline FHumanRec & Dummy variable of the functional area & Binary & $1=$ if the employee is in the human resources area; $0=$ no \\
\hline FJurLaw & Dummy variable of the functional area & Binary & $1=$ if the employee is in the juridic $\&$ law area; $0=$ no \\
\hline FMkt & Dummy variable of the functional area & Binary & $1=$ if the employee is in the marketing area; $0=$ no \\
\hline Fcom & Dummy variable of the functional area & Binary & $1=$ if the employee is in the commercial area; $0=$ no \\
\hline FEng & Dummy variable of the functional area & Binary & $1=$ if the employee is in the engineering area; $0=$ no \\
\hline FQual & Dummy variable of the functional area & Binary & $1=$ if the employee is in the quality area; $0=$ no \\
\hline FCallC & Dummy variable of the functional area & Binary & $1=$ if the employee is in call centers area; $0=$ no \\
\hline FLogis & Dummy variable of the functional area & Binary & $1=$ if the employee is in logistic area; $0=$ no \\
\hline Level & Hierachical level & Ordinal & $1=$ top, $2=$ middle manager, $3=$ technicians and $4=$ others \\
\hline Nationality & Dummy variable of share ownership & Binary & $1=$ if firm is national ownership; $0=$ no \\
\hline SConsum & Dummy variable of industry & Binary & $1=$ if the employee is in the consumption industry; $0=$ no \\
\hline SAuto & Dummy variable of industry & Binary & $1=$ if the employee is in the automotive industry; $0=$ no \\
\hline SDist & Dummy variable of industry & Binary & $1=$ if the employee is in the distribution industry; $0=$ no \\
\hline SElectr & Dummy variable of industry & Binary & $1=$ if the employee is in the electrical industry; $0=$ no \\
\hline SFarm & Dummy variable of industry & Binary & $1=$ if the employee is in the pharmaceutical industry; $0=$ no \\
\hline SChim & Dummy variable of industry & Binary & $1=$ if the employee is in the chemical industry \\
\hline SInd & Dummy variable of industry & Binary & $1=$ if the employee is in the industrial industry \\
\hline SServ & Dummy variable of industry & Binary & $1=$ if the employee is in the service industry \\
\hline SFin & Dummy variable of industry & Binary & $1=$ if the employee is in the finance industry \\
\hline STelec & Dummy variable of industry & Binary & $1=$ if the employee is in the telecommunication industry \\
\hline Dimension & Size of the firm & Interval & Number of employees \\
\hline Age & Age of employees & Interval & Number of years of the employees \\
\hline Tenure & Experience of employees & Interval & Number of years of experience of the employees \\
\hline Gender & Dummy variable of gender & Binary & $1=$ if the employee is female \\
\hline Education & Dummy variable of educational level & Binary & $1=$ if the employee has university degree \\
\hline Growth & Sales growth between 2002 and 2003 & Ordinal & $1=(<0 \%), 2=(0:+10 \%), 3=(>10 \%)$ \\
\hline Profitability & Variation of profits between 2002 and 2003 & Ordinal & $1=(<0 \%), 2=(0:+10 \%), 3=(>10 \%)$ \\
\hline
\end{tabular}




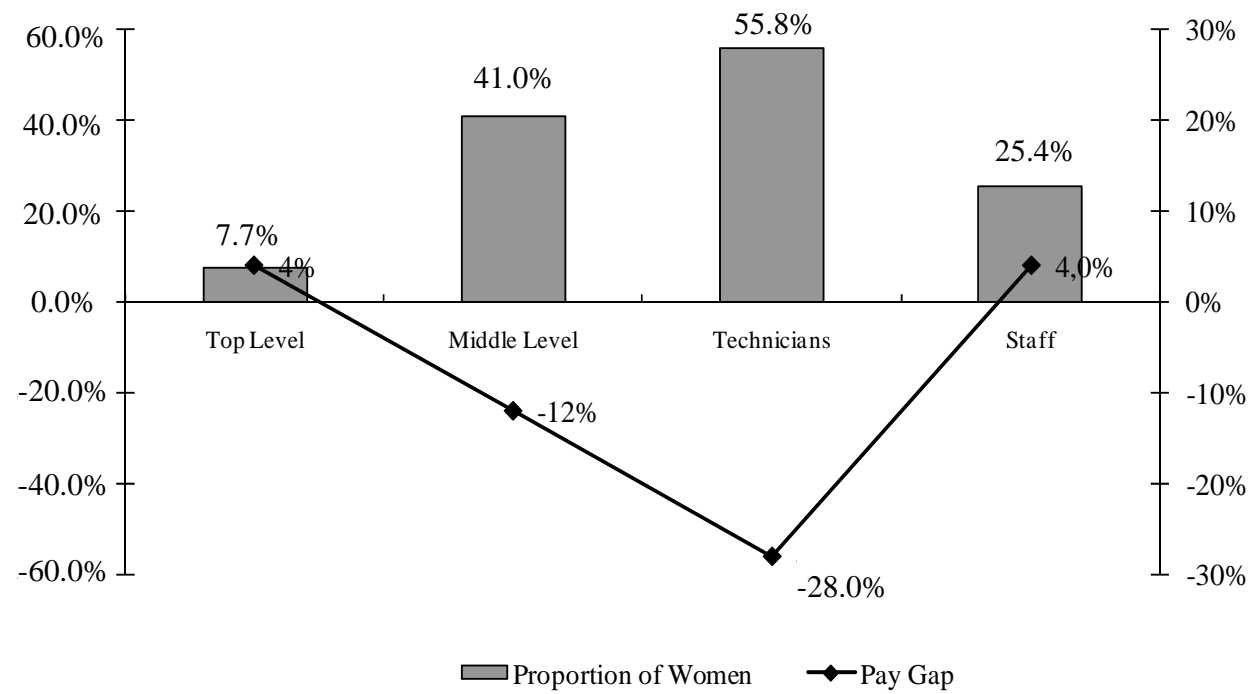

Fig. 1 Proportion of women and relative gender pay gap

Notes: Statistical analyses obtained with ANOVA outputs.

Table 3 Demographic gender variables and pay patterns

\begin{tabular}{|c|c|c|c|c|c|c|c|c|c|c|c|c|}
\hline & \multicolumn{6}{|c|}{ Managers } & \multicolumn{6}{|c|}{ Employees } \\
\hline & \multicolumn{3}{|c|}{ Top-level } & \multicolumn{3}{|c|}{ Middle-level } & \multicolumn{3}{|c|}{ Technicians } & \multicolumn{3}{|c|}{ Staff } \\
\hline & $\begin{array}{c}\text { Fem. } \\
\%\end{array}$ & $\begin{array}{l}\text { Rel. } \\
\text { Pay }^{\text {a }}\end{array}$ & $\begin{array}{l}\text { Pay } \\
\text { Gap }^{b}\end{array}$ & $\begin{array}{c}\text { Fem. } \\
\%\end{array}$ & $\begin{array}{l}\text { Rel. } \\
\text { Pay }^{\mathrm{a}}\end{array}$ & $\begin{array}{l}\text { Pay } \\
\text { Gap }^{\text {b }}\end{array}$ & $\begin{array}{c}\text { Fem. } \\
\%\end{array}$ & $\begin{array}{l}\text { Rel. } \\
\text { Pay }^{\mathrm{a}}\end{array}$ & $\begin{array}{l}\text { Pay } \\
\text { Gap }^{\mathrm{b}}\end{array}$ & $\begin{array}{c}\text { Fem. } \\
\%\end{array}$ & $\begin{array}{l}\text { Rel. } \\
\text { Pay }^{\text {a }}\end{array}$ & $\begin{array}{c}\text { Pay } \\
\text { Gap }^{\text {b }}\end{array}$ \\
\hline Overall & 7.70 & 1.00 & 0.04 & 41.00 & 1.00 & -0.12 & 55.80 & 1.00 & -0.28 & 25.40 & 1.00 & 0.04 \\
\hline \multicolumn{13}{|l|}{ Education } \\
\hline Lower & 0.00 & 0.00 & n.a. & 15.00 & 1.00 & -0.18 & 62.30 & 0.90 & -0.31 & 24.70 & 1.00 & 0.04 \\
\hline University & 8.70 & 1.00 & 0.04 & 32.30 & 1.00 & -0.11 & 37.40 & 1.30 & -0.04 & 64.40 & 1.10 & -0.09 \\
\hline \multicolumn{13}{|l|}{ Age } \\
\hline$<30$ & 0.00 & 0.00 & n.a. & 0.00 & 0.00 & n.a. & 33.30 & 0.90 & 0.03 & 16.70 & 0.60 & 0.15 \\
\hline $31-40$ & 0.00 & 0.00 & n.a. & 36.40 & 1.00 & -0.12 & 43.30 & 1.10 & -0.17 & 43.00 & 1.00 & 0.07 \\
\hline $41-55$ & 16.70 & 1.10 & -0.06 & 28.60 & 1.00 & -0.10 & 67.30 & 0.90 & -0.29 & 22.60 & 1.10 & -0.01 \\
\hline$>56$ & 0.00 & 0.00 & n.a. & 31.30 & 1.00 & -0.02 & 14.70 & 1.30 & 0.07 & 29.50 & 1.00 & 0.28 \\
\hline \multicolumn{13}{|l|}{ Tenure } \\
\hline$<5$ & 20.00 & 1.00 & -0.32 & 11.10 & 1.10 & 0.36 & 28.30 & 1.10 & 0.13 & 46.30 & 0.80 & 0.29 \\
\hline $6-15$ & 0.00 & 0.00 & n.a. & 26.20 & 1.00 & -0.10 & 34.80 & 1.20 & -0.05 & 21.70 & 0.90 & 0.14 \\
\hline $16-25$ & 12.50 & 1.20 & 0.18 & 44.80 & 1.00 & -0.09 & 75.40 & 0.80 & -0.29 & 24.90 & 1.10 & -0.02 \\
\hline$>26$ & 0.00 & 0.00 & n.a. & 28.60 & 0.90 & -0.19 & 36.00 & 1.10 & -0.20 & 46.90 & 1.00 & 0.07 \\
\hline
\end{tabular}

Notes: ${ }^{a}$ Ratio of the average pay by demographic category to the average pay in each hierarchical level; ${ }^{b}$ Ratio of the average pay of female managers/employees to the average pay of male managers/employees by demographic category minus one.

Female top-level managers earn 4 percent more than their male colleagues on average, and female middle-level managers are less than 12 percent. Female technicians earn 28 percent which is less than their male counterparts. This is the most significant wage gap we find. While female staff employees earn 4 percent more than their male colleagues. Similar to Bertrand and Hallock (2001), we find on average that females are paid 2.2 percent less than their male colleagues. In summary, our data strongly support the result that female managers are underrepresented in the highest paid and most prestigious jobs. Only a share of 0.2 percent of women fall into the upper level category, compared with five times as many as men in that top level position. The authors summarize 
statistics on demographic gender variables and pay patterns in Table 3.

Table 4 Firm type gender variables and pay patterns

\begin{tabular}{|c|c|c|c|c|c|c|c|c|c|c|c|c|}
\hline & \multicolumn{6}{|c|}{ Managers } & \multicolumn{6}{|c|}{ Employees } \\
\hline & \multicolumn{3}{|c|}{ Top-level } & \multicolumn{3}{|c|}{ Middle-level } & \multicolumn{3}{|c|}{ Technicians } & \multicolumn{3}{|c|}{ Staff } \\
\hline & $\begin{array}{c}\text { Fem. } \\
\%\end{array}$ & $\begin{array}{l}\text { Rel. } \\
\text { Pay }^{\mathrm{a}}\end{array}$ & $\begin{array}{c}\text { Pay } \\
\text { Gap }^{b}\end{array}$ & $\begin{array}{c}\text { Fem. } \\
\%\end{array}$ & $\begin{array}{l}\text { Rel. } \\
\text { Pay }^{\mathrm{a}}\end{array}$ & $\begin{array}{l}\text { Pay } \\
\text { Gap }^{\text {b }}\end{array}$ & $\begin{array}{c}\text { Fem. } \\
\%\end{array}$ & $\begin{array}{l}\text { Rel. } \\
\text { Pay }^{\text {a }}\end{array}$ & $\begin{array}{c}\text { Pay } \\
\text { Gap }^{\text {b }}\end{array}$ & $\begin{array}{c}\text { Fem. } \\
\%\end{array}$ & $\begin{array}{l}\text { Rel. } \\
\text { Pay }^{\text {a }}\end{array}$ & $\begin{array}{c}\text { Pay } \\
\text { Gap }\end{array}$ \\
\hline Overall & 7.70 & 1.00 & 0.04 & 41.00 & 1.00 & -0.12 & 55.80 & 1.00 & -0.28 & 25.40 & 1.00 & 0.04 \\
\hline \multicolumn{13}{|l|}{ Profitability } \\
\hline Negative & 0.00 & 0.80 & n.a. & 46.70 & 1.00 & -0.36 & 73.50 & 0.80 & -0.37 & 26.30 & 1.10 & -0.01 \\
\hline Middle positive & 11.10 & 1.10 & -0.03 & 26.70 & 1.00 & -0.12 & 27.10 & 1.20 & 0.17 & 19.60 & 0.80 & 0.17 \\
\hline High positive & 0.00 & 1.00 & n.a. & 22.20 & 1.00 & 0.26 & 42.50 & 1.20 & -0.24 & 45.20 & 0.80 & 0.27 \\
\hline \multicolumn{13}{|l|}{ Growth } \\
\hline Negative & 11.10 & 1.00 & -0.01 & 25.60 & 1.00 & -0.08 & 26.30 & 1.20 & 0.16 & 19.30 & 0.80 & 0.13 \\
\hline Middle positive & 0.00 & 0.90 & n.a. & 40.00 & 1.10 & -0.17 & 71.00 & 0.90 & -0.35 & 27.30 & 1.10 & -0.01 \\
\hline High positive & 0.00 & 0.90 & n.a. & 21.40 & 0.90 & -0.29 & 30.40 & 1.30 & -0.12 & 36.40 & 1.10 & 0.16 \\
\hline \multicolumn{13}{|l|}{ Firm size } \\
\hline $0-250$ & 0.00 & 1.00 & n.a. & 36.40 & 1.10 & -0.15 & 21.20 & 1.10 & 0.01 & 13.40 & 1.00 & 0.02 \\
\hline $251-500$ & 28.60 & 1.00 & 0.02 & 9.60 & 1.10 & 0.01 & 30.70 & 1.20 & -0.03 & 25.00 & 1.00 & -0.01 \\
\hline $501-1000$ & 0.00 & 1.20 & n.a. & 50.00 & 1.00 & -0.07 & 29.60 & 1.40 & 0.19 & 13.80 & 1.00 & 0.07 \\
\hline $1001-2000$ & 0.00 & 0.80 & n.a. & 23.80 & 0.90 & -0.33 & 25.70 & 1.40 & -0.23 & 26.60 & 0.90 & -0.16 \\
\hline $2001-5000$ & 0.00 & 1.00 & n.a. & 100.00 & 1.60 & n.a. & 0.00 & 1.70 & n.a. & 0.00 & 1.20 & n.a. \\
\hline.+5001 & 0.00 & 1.00 & n.a. & 45.50 & 0.80 & -0.11 & 78.40 & 0.80 & -0.29 & 51.90 & 1.00 & 0.28 \\
\hline \multicolumn{13}{|l|}{ Nationality } \\
\hline Multinational & 9.00 & 1.00 & -0.01 & 27.00 & 1.00 & -0.04 & 29.60 & 1.20 & 0.08 & 22.90 & 0.80 & 0.18 \\
\hline National & 0.00 & 0.80 & n.a. & 36.80 & 1.00 & -0.34 & 73.00 & 0.80 & -0.36 & 26.30 & 1.10 & -0.01 \\
\hline \multicolumn{13}{|l|}{ Function areas } \\
\hline Gen. Administration & 0.00 & 1.10 & n.a. & 16.70 & 1.00 & -0.24 & 40.00 & 1.70 & -0.05 & 59.50 & 1.00 & 0.09 \\
\hline Finance & 0.00 & 1.00 & n.a. & 55.00 & 1.00 & -0.14 & 38.50 & 1.30 & -0.05 & 47.60 & 1.00 & 0.03 \\
\hline $\mathrm{I} \& \mathrm{~T}$ & 0.00 & 0.90 & n.a. & 42.90 & 0.80 & -0.04 & 13.90 & 1.40 & -0.06 & 13.30 & 1.30 & 0.24 \\
\hline Hum. resources & 20.00 & 0.90 & -0.22 & 50.00 & 1.10 & -0.04 & 64.60 & 1.30 & -0.23 & 65.20 & 1.30 & -0.24 \\
\hline Jur. \& Law & 0.00 & 1.00 & n.a. & 25.00 & 1.00 & -0.11 & 33.30 & 1.30 & 0.07 & 0.00 & 1.00 & n.a. \\
\hline Marketing & 0.00 & 1.00 & n.a. & 25.00 & 1.00 & -0.12 & 64.80 & 0.80 & -0.25 & 36.50 & 0.90 & 0.00 \\
\hline Commercial & 0.00 & 1.00 & n.a. & 0.00 & 0.90 & n.a. & 25.00 & 1.40 & -0.23 & 0.10 & 1.10 & -0.21 \\
\hline Engin. & 0.00 & 1.00 & n.a. & 25.00 & 1.00 & -0.29 & 83.30 & 1.60 & -0.11 & 83.30 & 0.80 & -0.17 \\
\hline Quality & 0.00 & 1.00 & n.a. & 0.00 & 1.10 & n.a. & 7.10 & 1.20 & -0.33 & 12.00 & 0.70 & -0.15 \\
\hline Call centers & 100.00 & 1.30 & n.a. & 0.00 & 1.00 & n.a. & 23.10 & 1.80 & -0.07 & 78.00 & 1.00 & 0.44 \\
\hline Logistics & 0.00 & 1.00 & n.a. & 0.00 & 1.00 & n.a. & 25.00 & 0.70 & -0.13 & 0.00 & 1.00 & n.a. \\
\hline \multicolumn{13}{|l|}{ Activity sector } \\
\hline Consumption & 0.00 & 1.00 & n.a. & 33.30 & 1.10 & -0.17 & 41.70 & 1.80 & 0.25 & 23.50 & 0.90 & -0.29 \\
\hline Automotive & 0.00 & 0.80 & n.a. & 0.00 & 1.00 & n.a. & 26.70 & 1.10 & -0.12 & 8.60 & 0.60 & 0.14 \\
\hline Distribution & 16.70 & 1.20 & 0.15 & 50.00 & 1.10 & -20.00 & 44.00 & 1.80 & -21.00 & 40.90 & 1.00 & -0.13 \\
\hline Electric & 0.00 & 1.20 & n.a. & 0.00 & 1.10 & n.a. & 19.50 & 1.10 & -0.13 & 44.70 & 1.00 & 0.27 \\
\hline Pharmacy & 0.00 & 1.00 & n.a. & 40.00 & 0.80 & 0.05 & 25.90 & 1.40 & -0.04 & 66.70 & 1.30 & 0.10 \\
\hline Chemical & 16.70 & 0.90 & -22.00 & 29.40 & 0.80 & 0.12 & 20.30 & 1.00 & 0.22 & 26.10 & 0.90 & 0.10 \\
\hline Services & 0.00 & 0.90 & n.a. & 35.30 & 1.00 & -0.18 & 70.60 & 0.90 & -0.37 & 27.00 & 1.10 & 0.00 \\
\hline Finance & 0.00 & 1.00 & n.a. & 0.00 & 1.00 & n.a. & 50.00 & 1.20 & 0.27 & 66.70 & 1.30 & -0.02 \\
\hline
\end{tabular}

Notes: ${ }^{a}$ Ratio of the average pay by firm category to the average pay in each hierarchical level; ${ }^{b}$ Ratio of the average pay of female managers/employees to the average pay of male managers/employees by firm category minus one. 
Our results thus provide evidence for the existence of a glass ceiling. If gender were not an issue, that is, if the number of women in higher-paid positions were in line with overall employment patterns, then the percentage of female managers would be around 30 percent, which is the share of female in the whole sample. However, female technicians who are university educated and younger, even though that also means with less work experience, face a smaller pay gap than other female technicians. Having a university degree helps to close the pay gap among middle managers, and it closes still further with age. Table 4 shows that a significant percentage of female middle managers and technicians work for firms with negative profitability and average growth and those women experience the highest negative pay gap. However, the staff category does not present a similar pattern, as women benefit from higher pay gaps in firms with higher profitability and growth, where they are particularly well represented. Looking at the different functional areas, we see that women are represented in greater numbers in finance, human resources, and engineering. In these functional areas female middle managers and technicians are likely to earn more, but at the same time they are also likely to be paid somewhat less than their male counterparts.

\section{Methodology}

In order to achieve the goal of identifying the determinants of gender gap in earnings in Portuguese companies, this study uses separate Tobit models for man and women. Tobit model is highly favored by researchers when the dependent variable cannot take negative values, as it is the case of the amount of annual base pay. The authors estimated regressions of the pay of men and women separately.

This methodology allows understanding, separately for men and women, the propensity of each of the explanatory variables in broadening or narrowing the pay gap. Thus, the signal from each of the coefficients of variables indicates the positive or negative tendency that is associated with it. If the signals of the coefficients of the same variable for women and men are opposites which means that this variable has an impact of widening the existing gap, contributing to the maintenance and aggravation of the gender gap in pay.

\section{Empirical results}

Table 5 presents the estimation of the models on the determinants of gender pay and Fig. 2 presents the results of the regressions in a schematic form. Our findings indicate that there is a significant difference in the constant intercept for men and women, which reinforces the previous finding that men earn more than women on average.

The authors hypothesized that large firms would be more transparent in terms of their pay policies. Nonetheless, we find evidence of women achieving better pay in small firms in line with Becker (1957) and Hellerstein, et al (2002). Women are better paid in small firms (the estimated coefficient for men is statistically significant at 5\%). Affiliates of non-Portuguese firms appear to pay more to their employees, with women on average earning higher wages in foreign-held firms, thus supporting Aitkens, et al (1996). While firm growth does not seem to explain the gap, firm profitability seems to contribute towards increasing the gender pay gap, in contrast with Hellerstein, et al (2002), since men are more likely to have higher pay than women in more profitable firms.

When it comes to education, the results show that further education leads to higher wages on average, though the impact seems to be more significant for women, in line with Blau and Kahn (2007), and Chevalier (2007). But 
because women are less likely to hold top management positions, the gender pay gap can be partially explained by job segregation.

Table 5 Estimation of the models on determinants of gender pay

\begin{tabular}{|c|c|c|c|c|c|c|c|c|c|c|c|}
\hline \multirow{2}{*}{ Variable } & \multicolumn{6}{|c|}{ Estimation 1} & \multicolumn{5}{|c|}{ Estimation 2} \\
\hline & \multicolumn{3}{|c|}{ Male } & \multicolumn{3}{|c|}{ Female } & \multicolumn{2}{|l|}{ Male } & \multicolumn{3}{|c|}{ Female } \\
\hline FCALLC & -691.66 & & (767.39) & $4,978.54$ & $* * *$ & (540.59) & & & & & \\
\hline FCOM & $1,870.37$ & $* * *$ & (471.71) & $-5,866.64$ & $* *$ & $(2,600.17)$ & & & & & \\
\hline FENG & $-2,646.96$ & & $(2,956.42)$ & $-3,649.54$ & $* *$ & $(1,553.60)$ & & & & & \\
\hline FFIN & $-1,389.50$ & & (890.41) & -680.44 & & (747.69) & & & & & \\
\hline FHUM REC & $-1,320.10$ & & $(3,409.20)$ & $-4,306.72$ & $* *$ & $(2,198.75)$ & & & & & \\
\hline FIT & $-5,319.83$ & $* *$ & $(2,320.76)$ & -753.75 & & $(3,835.53)$ & & & & & \\
\hline FJUR LAW & $-9,210.61$ & $* * *$ & $(3,014.37)$ & $-6,075.24$ & & $(4,406.97)$ & & & & & \\
\hline FLOGIST & $-16,711.29$ & & $(10,974.17)$ & $-3,411.16$ & & $(3,891.72)$ & & & & & \\
\hline FMKT & $-12,055.02$ & $* * *$ & $(1,569.88)$ & $-10,106.67$ & $* * *$ & $(1,626.64)$ & & & & & \\
\hline SCHIM & $-6,462.04$ & $* *$ & $(2,730.20)$ & $-3,152.32$ & & $(2,058.60)$ & & & & & \\
\hline SCONSUM & 28.14 & & $(2,969.42)$ & $2,002.86$ & & $(2,739.87)$ & & & & & \\
\hline SDIST & $7,786.37$ & * & $(4,859.26)$ & $3,453.86$ & & $(3,628.62)$ & & & & & \\
\hline SAUTOM & $-6,266.81$ & $* *$ & $(2,846.18)$ & $-6,279.69$ & $* * *$ & $(2,446.97)$ & & & & & \\
\hline SELECTR & -631.24 & & $(3,164.26)$ & $-3,622.46$ & & $(2,322.10)$ & & & & & \\
\hline SFARM & -8.43 & & $(3,084.56)$ & $-2,137.95$ & & $(2,602.16)$ & & & & & \\
\hline AGE & $1,610.23$ & $* * *$ & (400.04) & $2,634.43$ & & (636.26) & $1,639.96 * * *$ & (386.63) & $1,936.93$ & $* * *$ & (622.90) \\
\hline DIMENSION & 0.35 & & (1.36) & -0.23 & & (0.59) & $2.14 * *$ & (0.09) & -0.58 & & $(0.54)$ \\
\hline EDUCATION & $1,124.15$ & & $(1,506.07)$ & $6,912.00$ & $* * *$ & $(1,183.44)$ & $4,274.55 * * *$ & $(1,337.43)$ & $5,608.78$ & $* * *$ & $(1,200.40)$ \\
\hline GROWTH & $-2,293.71$ & & $(1,627.85)$ & $-1,183.56$ & & $(1,528.32)$ & $-1,491.12$ & $(1,007.23)$ & -497.86 & & $(1,096.21)$ \\
\hline LEVEL & $-23,300.47$ & $* * *$ & $(1,397.67)$ & $-13,920.72$ & $* * *$ & $(1,700.76)$ & $-19,320.97 * * *$ & $(1,140.97)$ & $-14,335.67$ & $* * *$ & $(1,593.02)$ \\
\hline NATIONALITY & $-3,859.67$ & & $(10,789.00)$ & $-6,065.15$ & * & $(3,569.17)$ & $-9,600.05$ & $(7,124.95)$ & $-3,397.32$ & & $(3,710.90)$ \\
\hline PROFITABILITY & $2,282.77$ & $* *$ & $(1,130.68)$ & -696.40 & & $(1,573.52)$ & $4,271.23 * * *$ & $(1,176.09)$ & -621.22 & & $(1,320.52)$ \\
\hline TENURE & 89.40 & & (185.60) & -13.01 & & (289.84) & 20.41 & $(2,04.00)$ & 85.59 & & (276.31) \\
\hline TENURE2 & -2.27 & & (4.27) & -0.77 & & $(7.00)$ & -2.69 & (4.57) & -2.47 & & (6.66) \\
\hline AGE2 & -16.22 & $* * *$ & $(4.51)$ & -25.78 & $* * *$ & (7.47) & $-15.40 * * *$ & (4.38) & -18.55 & $* * *$ & (7.36) \\
\hline SECTCOM & & & & & & & $8,297.00 * * *$ & (879.35) & $7,284.48$ & $* * *$ & $(1,674.65)$ \\
\hline SECTSERV & & & & & & & $2,847.84 *$ & $(1,564.97)$ & $1,731.35$ & & $(1,483.86)$ \\
\hline FGFIN & & & & & & & $-5,144.78$ & $(3,936.50)$ & $4,007.89$ & $* *$ & $(2,092.51)$ \\
\hline FGOTHERS & & & & & & & $-2,974.14$ & $(3,865.57)$ & $9,834.24$ & $* * *$ & $(2,425.34)$ \\
\hline FGTECHN & & & & & & & $-2,507.56$ & $(3,876.89)$ & $-1,553.57$ & & $(1,875.22)$ \\
\hline FGCOM & & & & & & & $-4,609.29$ & $(3,895.36)$ & $-5,313.19$ & $* * *$ & $(2,020.12)$ \\
\hline $\mathrm{C}$ & 71115.03 & $* * *$ & (10590.17) & 15362.33 & & (14465.79) & $43,937.69 * * *$ & $(10,691.56)$ & $24,188.69$ & $* *$ & $(13,062.27)$ \\
\hline R-squared & & & 0.81 & & & 0.71 & & 0.75 & & & 0.72 \\
\hline Adjusted R-squared & & & 0.81 & & & 0.71 & & 0.75 & & & 0.71 \\
\hline S.E. of regression & & & $5,214.86$ & & & $4,782.66$ & & $5,936.84$ & & & $47,24.90$ \\
\hline Sum squared resid & & & $7.31 \mathrm{E}+10$ & & & $2.66 \mathrm{E}+10$ & & $9.50 \mathrm{E}+10$ & & & $2.62 \mathrm{E}+10$ \\
\hline Log likelihood & & & -27.11284 & & & $-11,775.04$ & & $-27,450.25$ & & & $-11,762.05$ \\
\hline Avg. log likelihood & & & -9.98 & & & -9.88 & & -10.11 & & & -9.87 \\
\hline Uncensored obs & & & 2.715 & & & 1.191 & & 2.715 & & & 1.191 \\
\hline Mean dependent var & & & $18,150.29$ & & & $18,099.02$ & & $18,150.29$ & & & $18,099.02$ \\
\hline Akaike info criterion & & & 19.99 & & & 19.81 & & 20.23 & & & 19.78 \\
\hline Schwarz criterion & & & 20.05 & & & 19.93 & & 20.27 & & & 19.86 \\
\hline Total obs & & & 2.715 & & & 1.191 & & 2.715 & & & 1.191 \\
\hline
\end{tabular}

Notes: For the meaning of the variables see Table 1 . Standard errors are in parenthesis; ${ }^{*} \mathrm{p}<0.1,{ }^{* *} \mathrm{p}<0.05,{ }^{* * *} \mathrm{p}<0.01$; Dependent variable is the annual base pay. Tobit models estimated by maximum likelihood, using the econometrics software Eviews. Method: ML-Censored Normal (Tobit) (Quadratic hill climbing), using QML (Huber/White test) standard errors \& covariance. In estimation 1 the omitted variables are FGENADM, FQUAL, SFIN and STELEC. In estimation 2 the omitted variables are SECTIND and FGHUMREC. 
While less experienced men and women earn lower wages, men are found to reach top salaries much quickly, with wages further increasing with age and tenure. In fact, men tend to reach peak pay between the ages of 41 to 55, compared with women who manage so during the following stratum. We found that the coefficients of the hierarchical level variable are negative (the level variable takes on smaller values the higher the hierarchical level; please refer to Table 2 for the description of the variables) and with highly significant, but this likelihood is higher for men, thus contributing to a higher gender pay gap in these hierarchical ladders. This evidence of the existence of a "glass ceiling” supports Arulampalam, et al (2007), Adams, et al (2009) and Ryan and Haslam (2009), among others.

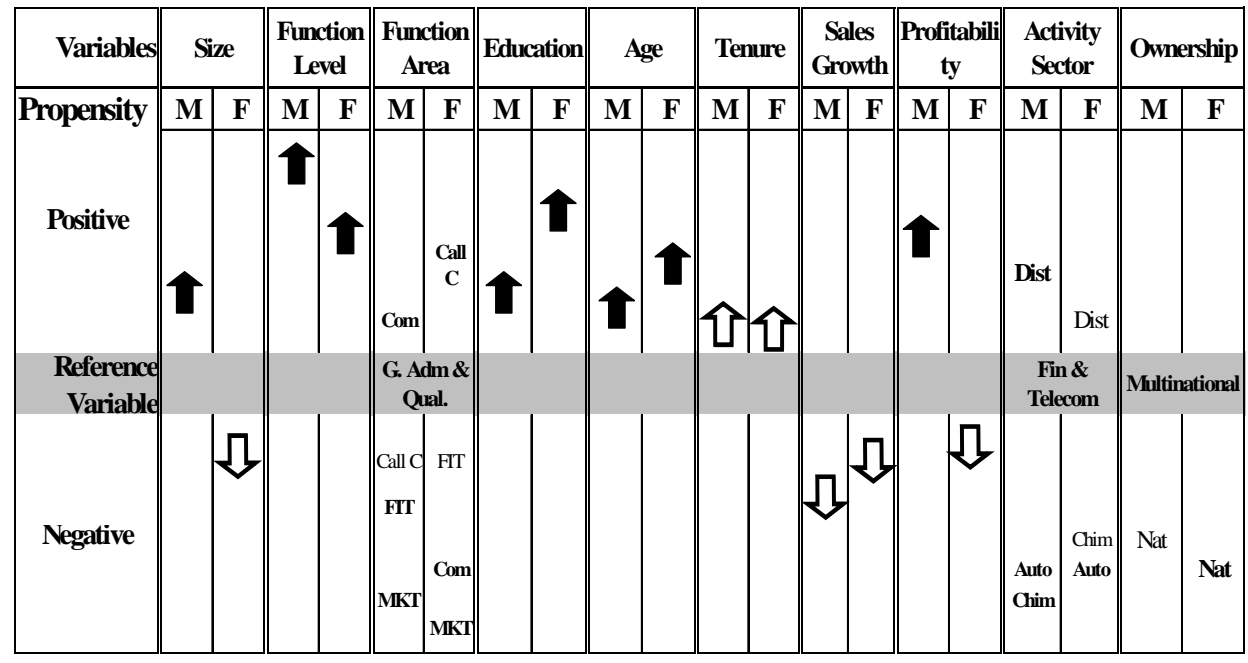

Fig. 2 Determinants of the gender pay gap

Notes: Dependent variable is the annual base pay. The highest the propensity difference, in each explanatory variable, the highest the gender pay gap. Summary results obtained from Tobit models estimated by maximum likelihood, using econometric model Eviews. Method: ML-Censored Normal (TOBIT) (Quadratic hill climbing), using QML (Huber/White test) standard errors \& covariance. Black arrows and bold lettering mean statistically significant values at the $5 \%$ significance level.

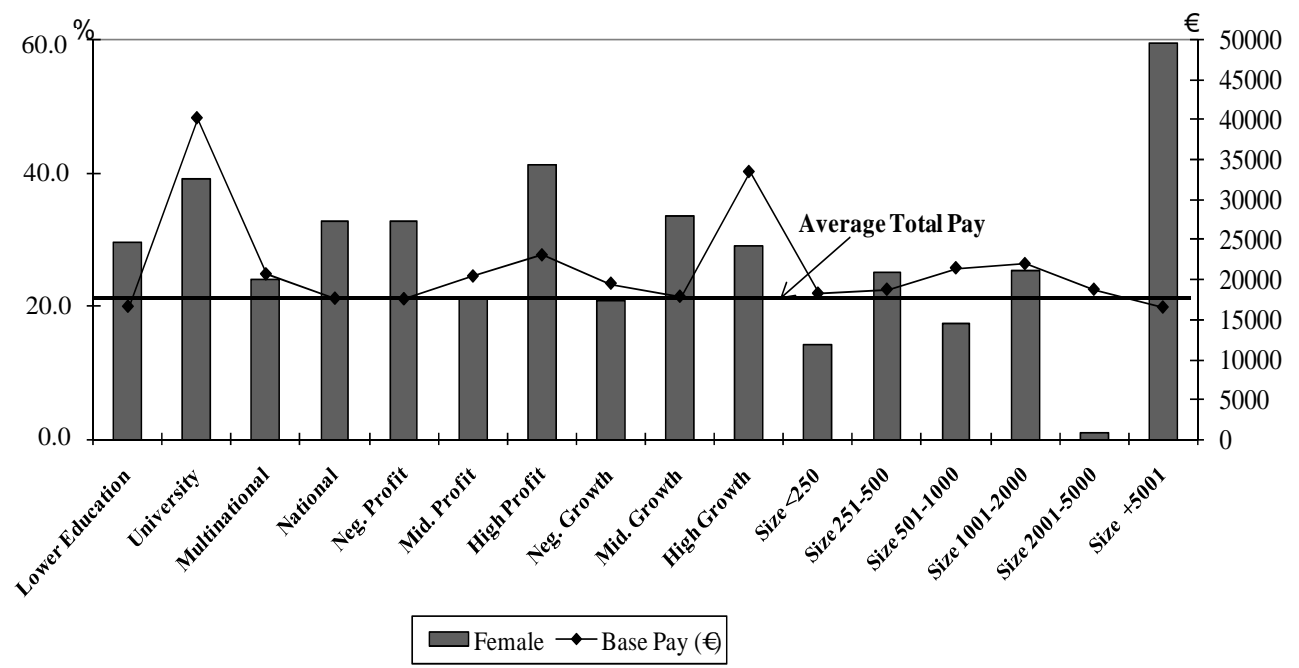

Fig. 3 Relative representation of women and pay, compared with average pay

Notes: This figure combines information to test the correlation of average pay with the weight of women's representation. Average pay for each variable presents a weak relation to the proportion of women. Columns represent the percentage of women in each determinant and line represents the average base pay. 


\section{Conclusions}

The main objective of our research was to examine the determinants of pay by gender in a small European country. While there have been a number of previous studies based on different data samples and in different cultures that show evidence of a significant wage gap between men and women, the authors found only scant and nuanced evidence of a gap of negative 2.2 percent. Our findings may have also been different if we had considered part-time work, which is often lower paid, the fairness of which might be argued. The authors did not find that when women make up a large proportion of workers, wages are necessarily depressed. With our results, it seems reasonable to accept that gender pay determinants are similar for women and men, which is not to say that there are not steps to be taken by society, and specifically by firms, to eliminate the disparity that does exist.

Despite the progress in the labor market made by women in recent years, only a small percentage has actually managed to reach top positions, so there can be no doubt that the "glass ceiling" is still existed. There is some encouraging evidence that women have turned to a variety of jobs traditionally held by men, while at the same time, women do not appear to be improperly penalized in case of career interruption to handle family responsibilities. Some countries already have carried out legislation on gender equality. This setup is particularly important for women wishing to actively participate in informal networks and lobbying activities, and ultimately reduce the "glass ceiling" phenomenon. In summary, new ways should be pursued to efficiently address such as, combining work and family commitments and leveling the playfield for women in a fair way.

One of the ways to close the gender pay gap is for policymakers to do more to help families in achieving that. Not only are women demanding a better balance between home and work, but men are as well. Some policy initiatives such as, mandatory paid sick days and family leave, public support for childcare, and increasing the viability of flexible workplaces without pay penalties, are important steps that have encouraged men to take on more of housework and childcare responsibilities. In the long run, the increasing availability of public policies will make it easier for both sexes to combine work and family.

Labor markets currently fail to address issues related to combining work and family commitments. Additionally, we would not say that economies are not limited pies - that is, if women do better, then men must do worse. Nonetheless, since we analyze female pay relative to male pay, if women do better in relative terms, by definition, men will not continue to have a relative advantage. In summary, new ways should be found to level the playing field for women, while at the same time not penalizing men.

One interesting extension of this study would be to look at data by company, for over several years. Data per employee, per firm, or both would allow for a dynamic study of career development and compensation package variations for middle managers in relation to human capital variables, firm performance variables and job characteristics. Clearly, more research is needed to shed light on the remaining, if evolving, gender pay gap.

\section{References:}

Adams, S. M., Gupta, A. \& Leeth, J.. (2009). Are female executives over-represented in precarious leadership positions? British Journal of Management, 20, 1-12.

Agell, J. \& Bennmarker, H.. (2007). Wage incentives and wage rigidity: A representative view from within. Labour Economics, 14, 347-369.

Aitkens, B., Harrison, A. \& Lipsey, R.. (1996). Wages and foreign ownership: A comparative study of Mexico, Venezuela and the United States. Journal of International Economics, 40, 345-371.

Almquist, E. M.. (1987). Labor market gender inequality in minority groups. Gender and Society, 1, 400-414.

Arulampalam, W., Booth, A. \& Bryan, M.. (2007). Is there a glass ceiling over Europe? Exploring the gender pay gap across the 
wages distribution. Industrial and Labor Relation Review, 60, 163-186.

Babcock L. \& Laschever, S.. (2003). Women don't ask: Negotiation and the gender divide. Princeton: Princeton University Press.

Becker, G. S.. (1957). The economics of discrimination. Chicago: University of Chicago Press.

Bertrand, M. \& Hallock, K.. (2001). The gender gap in top corporate jobs. Industrial and Labor Relations Review, 55, 3-21.

Blanchflower, D. G., Oswald, A. \& Sanfey, P.. (1996). Wages, profits and rent-sharing. Quarterly Journal of Economics, 111, 227-251.

Blau, F. \& Kahn, M.. (2007). The gender pay gap: Have women gone as far as they can? Academy of Management Perspectives, 21, 7-23.

Boushey, H.. (2008). Opting out? The effect of children on women's employment in the United States. Feminist Economics, 14, 1-36.

Bowlin, W. \& Renner, C.. (2008). Assessing gender and top-management-team pay in S\&P mid-cap and small-cap. European Journal of Operational Research, 185, 430-437.

Brown, C. \& Medoff, J.. (1989). The employer size wage effect. Journal of Political Economy, 97, 1027-1059.

Chevalier, A.. (2007). Education, occupation and career expectations: determinants of the gender pay gap for UK graduates. Oxford Bulletin of Economics and Statistics, 69, 819-842.

Cornelius, N. \& Skinner, D.. (2008). The careers of senior men and women—A capabilities theory perspective. British Journal of Management, 19, 141-149.

Duarte, C., Esperança, P. \& Curto, J.. (2006). Determinantes da remuneração variável nas empresas portuguesas. Revista Alcance, 13, 329-353.

Gibbons, R. \& Katz, L.. (1992). Does unmeasured ability explain inter-industry wage differentials? Review of Economic Studies, 59, 515-535.

Gneezy, U., Niederle, M. \& Rustichini, A.. (2003). Performance in competitive environments: Gender differences. Quarterly Journal of Economics, 118, 1049-74.

Hellerstein, J., Neumark, D. \& Troske, K.. (2002). Market forces and sex discrimination. Journal of Human Resources, 37, $896-914$.

Huffman, M. L. \& Velasco, S. C.. (1997). When more is less: Sex composition, organizations and earnings in U.S. firms. Work and Occupations, 24, 214-244.

International Trade Union Confederation. (2008, February). The global pay gender gap.

Jacobs, J. A.. (1992). Women's entry into management: Trends in earnings, authority and values among salaried managers. Administrative Science Quarterly, 37, 282-301.

Kunze, A.. (2005). The evolution of the gender wage gap. Journal of Labor Economics, 12, 73-97.

Mincer, J.. (1974). Schooling, experience and earnings. New York: National Bureau of Economic Research.

Neathey F., Dench, S. \& Thomson, L.. (2003). Monitoring progress towards pay equality. EOC Research Discussion Series.

Neumark, D.. (1993). Sex discrimination and women's labor market interruptions. (Working paper, No. 4260, NBER)

Pfeffer, J. \& Davis-Blake, A.. (1987). The effect of the proportion of women on salaries: The case of college administrators. Administrative Science Quarterly, 32, 1-24.

Phillips, D.. (2005). Organizational genealogies and the persistence of gender inequality: The case of Silicon Valley law firms. Administrative Science Quarterly, 50, 440-472.

Reilly, K. T. \& Wirjanto, T. S.. (1999). Does more lean less? The male/female wage gap a proportion of females at the establishment level. Canadian Journal of Economics, 32, 906-929.

Ryan, M. \& Haslam, S.. (2009). Glass cliffs are not so easily scaled: On the precariousness of female CEOs' positions. British Journal of Management, 20, 13-16.

Selmer, J. \& Leung, A. S.. (2003). Are corporate career development activities less available to female than to male expatriates? Journal of Business Ethics, 43, 125-136.

Van der Meer, P.. (2008). Is the gender wage gap declining in the Netherlands? Applied Economics, 40, 146-160.

Yurtoglu, B. \& Zulehner, C.. (2007). The gender gap in top corporate jobs is still there. Retrieved from http://homepage.univie.ac.at/Christine.Zulehner/ceo.pdf. 